\section{Individual-based approach as a useful tool to disentangle the relative importance of tree age, size and inter-tree competition in dendroclimatic studies}

\section{Vicente Rozas}

In this work, an individual-based approach was used to assess the relative importance of tree age, size, and competition in modulating the individual dendroclimatic response of Quercus robur L. This was performed in a multi-aged forest in northwestern Spain under a wet Atlantic climate. All trees in five replicated forest stands with homogeneous soil conditions were mapped and inter-tree competition was quantified with a distance-dependent competition index. Tree rings of cored trees were crossdated and total age was estimated on individuals where the pith was missed. The climatic response was evaluated by bootstrapped correlations of individual tree-ring chronologies with climatic records. Inter-annual growth variation, i.e., mean sensitivity, was independent of tree age and bole diameter, but modulated by competition. Water excess in previous summer-autumn and spring negatively affected growth, while warmer September conditions favored growth. Individual response to climate was independent of tree age, but related to the joint effect of tree bole diameter and competition. Larger oaks in less competitive environments responded more plastically to climatic stress, while smaller trees under high competition levels were less responsive to climate. Strong inter-tree competition reduced growth plasticity but amplified the vulnerability of smaller oaks to the particularly rainy conditions of the study area. These findings suggest that inter-tree competition is a relevant size-mediated extrinsic factor that can potentially modulate individual radial growth variation and its response to limiting climatic conditions in temperate deciduous forests. This study highlights the value of individual-based approach as a useful tool that informs about the relative contribution of factors modulating the climatic response of tree-ring growth.

Keywords: Climate-Growth Response, Competitive Effect, Dendroecology, Individual Variation, Quercus robur, Size Effect, Tree Age

\section{Introduction}

There is an ongoing debate on the potential role of intrinsic tree traits, such as age and size, in modulating the response of radial growth to climate. An earlier study demonstrated that the individual response of Picea glauca (Moench) Voss. radial growth to summer temperature may be age dependent, and that this dependence may be modulated by local site hydrology (Szeicz \& MacDo-

nald 1994). Further investigations revealed that lower temperatures near the alpine timberline can be more limiting for growth of old than young conifer trees (Carrer \& Urbinati 2004, Yu et al. 2008). Furthermore, older deciduous oaks were shown to be more responsive to water availability than younger ones under temperate climate conditions (Rozas 2005, Copenheaver et al. 2011). Recent studies with Mediterranean conifers es-

Laboratorio de Dendrocronología, Facultad de Ciencias Forestales, Universidad Austral de Chile, casilla 567, Valdivia (Chile)

@ Vicente Rozas (vicenterozas@gmail.com)

Received: Jan 20, 2014 - Accepted: May 25, 2014

Citation: Rozas V, 2015. Individual-based approach as a useful tool to disentangle the relative importance of tree age, size and inter-tree competition in dendroclimatic studies. iForest 8: 187-194 [online 2014-08-21] URL: http://www.sisef.it/iforest/contents/? id=ifor $1249-007$

Communicated by: Francesco Ripullone tablished that younger trees, with a poorly developed root system and a longer growing season, were more sensitive to drought than older trees (Rozas et al. 2009, Vieira et al. 2009). Therefore, age-modulated radial growth response to climate has been suggested as a widespread phenomenon that can involve different tree species growing under diverse environmental conditions (Szeicz \& MacDonald 1994, Carrer \& Urbinati 2004). Even if tree-ring series used for climate reconstructions are generally taken from oldest trees growing in limiting environments, agerelated changes in the climatic signal could potentially affect the interpretation of dendroclimatic reconstructions (Esper et al. 2008).

Tree size is also known to potentially modulate the climatic sensitivity of radial growth (Martín-Benito et al. 2008, De Luis et al. 2009, Mérian \& Lebourgeois 2011), because a number of essential physiological processes including soil nutrient uptake, xylem water flux, photosynthetic rates, and movement of growth hormones are all strongly mediated by size (Phillips et al. 2003, Mencuccini et al. 2005, Rossi et al. 2008, Thomas 2010). At water-limited sites, smaller trees demonstrate greater sensitivity to summer drought (De Luis et al. 2009, Linares et al. 2010); however, at sites where water is less limiting, larger trees have the highest sensitivity to drought (Piutti \& Cescatti 1997, Mérian \& Lebourgeois 2011). Concurrently with the inherent link between tree age and size, all this evidence suggests that species-specific physiological and/or morphological shifts during tree ontogeny, combined with site-specific limiting environmental conditions, can lead to age- or sizeinduced growth responses to climate.

Physiological studies assessing the effects of age and size on tree vigor concluded that extrinsic factors mediated by size, such as decreased soil nutrient availability or asymmetric inter-tree competition, could be even more important than age or size in modulating tree reaction to stresses (Day et al. 2002, Mencuccini et al. 2005). Competition among neighboring trees is an extrinsic stressor that greatly influences water and nutrient uptake, light interception, carbon assimilation, and ultimately determines tree vitality and survival in dense temperate forests (Olano et al. 2009, Gómez-Aparicio et al. 2011). Intertree competition can also potentially modulate the biological response of trees to longterm climate variation (Piutti \& Cescatti 1997, Linares et al. 2010, Martín-Benito et al. 2011). Despite considerable effort being devoted to understand both age- and sizemodulated radial growth responses to climate, little research has been undertaken regarding the importance of competition in modulating the dendroclimatic response at 


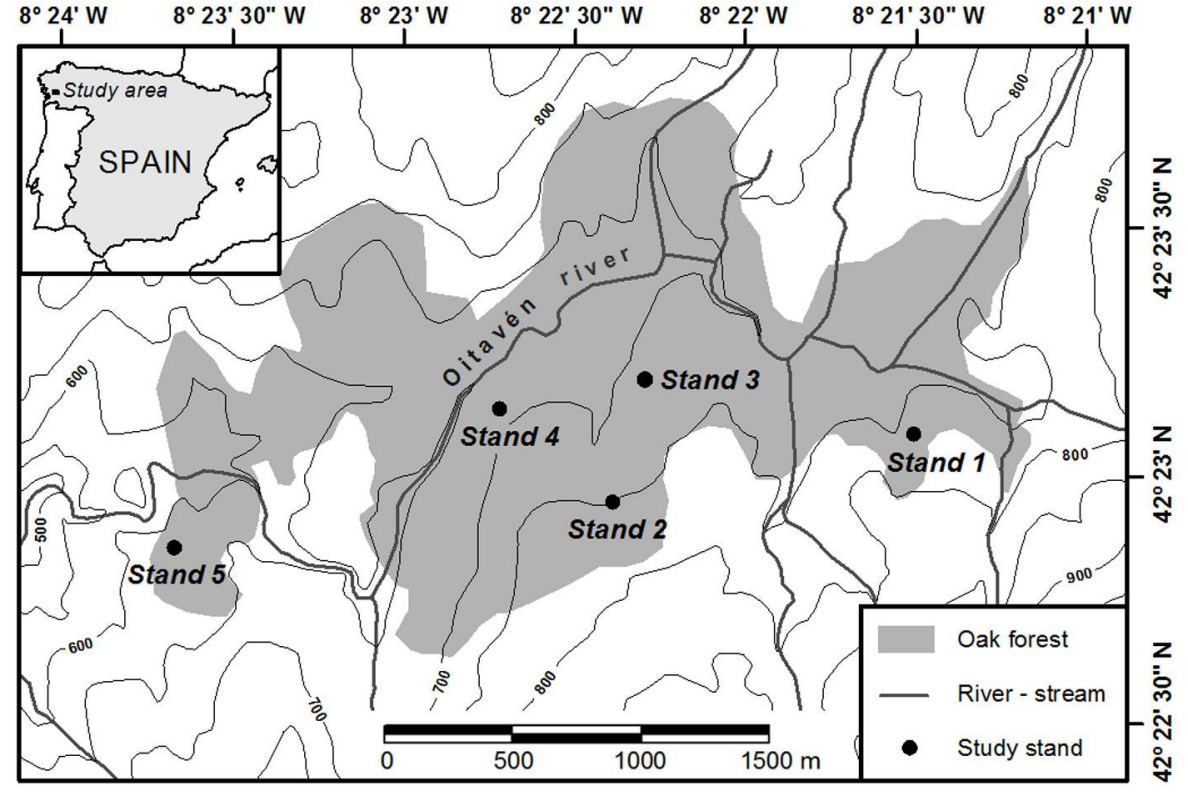

Fig. 1 - Location of the study area in north-western Spain, and of the five study stands within the multi-aged oak forest. Contour lines indicate $50 \mathrm{~m}$ elevation intervals.

stand level (Hurteau et al. 2007, Gea-Izquierdo et al. 2009, Castagneri et al. 2012). However, no research has been undertaken to date regarding this topic at individual level.

In this paper, I use an individual-based approach to assess the relative importance of tree age, size, and inter-tree competition on the individual response of radial growth to climate in a multi-aged pedunculate oak (Quercus robur L.) forest under Atlantic climate conditions in the Serra do Suido mountain range, northwestern Spain. The specific aims of this study were to quantify the relationships between tree age, size, and competition intensity in a multi-aged pedunculate oak forest, to evaluate the individual variability in radial growth responses to climate under wet Atlantic conditions, and to determine the relative contribution of tree age, size, and inter-tree competition in modula-

ting individual radial growth variation and its response to limiting climatic conditions.

\section{Material and methods}

\section{Study area}

The Serra do Suido is a mountain range with a maximum elevation of $1151 \mathrm{~m}$ in the Pontevedra province, Galicia, north-west Spain. Upland heath dominates on the deforested slopes while oak woodlands are found on valley bottoms. The dominant woodland is an Ibero-Atlantic acidophilous oak forest (G1.8/P-41.56, EUNIS habitat classification) almost exclusively composed of pedunculate oak, with a sparse understorey of Ilex aquifolium L., Pyrus cordata Desv., and Crataegus monogyna Jacq.

Soils are acidic, nutrient-poor Lithic and Umbric Leptosols and Epileptic Umbrisols on granite bedrock (Calvo de Anta \& Macías

Tab. 1 - Traits of study stands and sampled trees in the Serra do Suido range, north-western Spain. (DBH): tree bole diameter at $1.30 \mathrm{~m}$ above ground; (Soil texture): soil proportion with size $<2 \mathrm{~mm}$; $(\mathrm{OM})$ : organic matter content; (a): Mean \pm SD.

\begin{tabular}{|c|c|c|c|c|c|}
\hline Traits & Stand 1 & Stand 2 & Stand 3 & Stand 4 & Stand 5 \\
\hline Elevation (m) & 770 & 750 & 720 & 690 & 610 \\
\hline Aspect & $\mathrm{N}$ & NE & NW & N-NE & $\mathrm{N}-\mathrm{NW}$ \\
\hline Slope (\%) & 26 & 27 & 25 & 30 & 28 \\
\hline Total tree density $\left(\mathrm{ha}^{-1}\right)$ & 305 & 360 & 440 & 430 & 455 \\
\hline Total basal area $\left(\mathrm{m}^{2} \mathrm{ha}^{-1}\right)$ & 35.1 & 28.5 & 27.3 & 32.0 & 28.5 \\
\hline Tree age $(y r)^{a}$ & $162 \pm 18$ & $105 \pm 42$ & $102 \pm 12$ & $102 \pm 27$ & $120 \pm 23$ \\
\hline $\mathrm{DBH}(\mathrm{cm})^{\mathrm{a}}$ & $38.0 \pm 7.5$ & $28.5 \pm 9.2$ & $28.8 \pm 7.3$ & $31.5 \pm 8.0$ & $28.2 \pm 6.6$ \\
\hline Competition index ${ }^{a}$ & $1.4 \pm 1.0$ & $2.1 \pm 1.8$ & $2.5 \pm 2.2$ & $2.5 \pm 1.6$ & $2.3 \pm 1.5$ \\
\hline Soil texture $(\%)^{\text {a }}$ & $74.1 \pm 6.9$ & $74.8 \pm 4.7$ & $79.8 \pm 5.3$ & $72.8 \pm 6.2$ & $68.1 \pm 8.1$ \\
\hline Soil OM $(\%)^{a}$ & $22.6 \pm 2.9$ & $23.8 \pm 2.6$ & $20.9 \pm 4.4$ & $20.6 \pm 4.2$ & $20.5 \pm 5.6$ \\
\hline Soil $\mathrm{pH}\left(\mathrm{H}_{2} \mathrm{O}\right)^{\mathrm{a}}$ & $3.7 \pm 0.1$ & $3.8 \pm 0.2$ & $3.9 \pm 0.2$ & $3.8 \pm 0.2$ & $3.6 \pm 0.3$ \\
\hline
\end{tabular}

Vázquez 2002). Climate is temperate and humid, with a mean annual temperature of $12.0^{\circ} \mathrm{C}$, and a mean annual precipitation of $1315 \mathrm{~mm}$ for 1901-2006. Total annual precipitation in the study area significantly increased throughout the $20^{\text {th }}$ century, and particularly rainy conditions were recorded in 2001, with $2163 \mathrm{~mm}$ in total annual precipitation. Seasonal water excess in recent decades, and particularly the extremely rainy conditions in 2001, caused oak decline in this forest (Rozas \& García-González 2012).

\section{Sampling and soil traits assessment}

A 385-ha wooded section on the windward side of the Serra do Suido was selected for study $\left(42^{\circ} 22^{\prime} 40^{\prime \prime}-42^{\circ} 23^{\prime} 50^{\prime \prime} \mathrm{N}, 08^{\circ} 21^{\prime \prime}\right.$ $10^{\prime \prime}-08^{\circ} 23^{\prime} 45^{\prime \prime}$ W; Fig. 1). A replicated sampling was performed in five representative forest stands located at elevations between 610-770 m a.s.l., mainly facing north and with mean slopes of $25-30 \%$ (Tab. 1). Total tree density in these stands varied between 305 and 455 trees $\mathrm{ha}^{-1}$, and total basal area between 28.5 and $35.1 \mathrm{~m}^{2} \mathrm{ha}^{-1}$. In 2007 , a rectangular study plot of $60 \times 70 \mathrm{~m}$ was randomly established within each stand, and all oaks found within the plots were mapped with a laser total station (Pentax ${ }^{\circledR}$ R-325 NX). All trees were tagged and their DBH (stem diameter at $1.3 \mathrm{~m}$ above the ground) was measured. Thirty trees with DBH $>10$ $\mathrm{cm}$ were randomly selected within an inner rectangle of $40 \times 50 \mathrm{~m}$ centered inside each study plot for wood core sampling. Two wood cores were collected along opposing radii oriented parallel to the slope contour line from each of the thirty selected trees per plot, using increment borers at breast height. Additionally, in order to assess the variability of soil traits, three soil samples comprising the first $10 \mathrm{~cm}$ of soil were randomly taken at $1.5 \mathrm{~m}$ from the stem base around fifteen randomly selected trees per stand with a 5-cm diameter soil core sampler, which were pooled into a single composite soil sample per tree. Soil samples were sieved at $2 \mathrm{~mm}$ and air-dried, organic matter content was determined by combustion $\left(500{ }^{\circ} \mathrm{C}, 4 \mathrm{~h}\right)$, and soil $\mathrm{pH}$ measured with a glass electrode in distilled water solution (water:soil, 1:2.5).

\section{Inter-tree competition assessment}

Inter-tree competition was quantified on the thirty selected trees per plot with a distance-dependent competition index $(C I)$. Basal area $\left(B A, \mathrm{~cm}^{2}\right)$ of each tree was computed from its geometrical radius, and competition intensity was quantified as (Lorimer 1983 eqn. 1):

$$
C I=\sum_{j=1}^{n(R)} \frac{B A_{j} / B A_{i}}{D_{i j}}
$$

where $B A_{\mathrm{i}}$ is the basal area of subject tree $i$, $B A_{\mathrm{j}}$ is the basal area of competitor tree $j$ within the search radius $R$, and $D_{\mathrm{ij}}$ is the dis- 
tance (m) between subject tree $i$ and competitor tree $j$. Competitors are defined as those oaks with DBH $>10 \mathrm{~cm}$ included inside a prescribed search radius $R$ equal to $8 \mathrm{~m}$ from the subject tree, which is coherent with that previously used in other studies (Piutti \& Cescatti 1997, Linares et al. 2010). The $C I$ varies as a direct function of the relative size of competitors in comparison to the subject tree, and an inverse function of the distances between competitors and the subject tree.

\section{Dendrochronological procedures}

The cores were processed and tree-ring series were visually dated by matching the patterns of narrow and wide rings (Yamaguch 1991). In cores where the pith was missed, tree age at coring height was estimated with a mean absolute error of \pm 4 yrs, according to a method based on the convergence of xylem rays at the pith to estimate the length of the missing radius, and on an empirical model of initial radial growth to estimate the number of missing rings (Rozas 2003). Series of total tree-ring width were measured on each core to the nearest $0.001 \mathrm{~mm}$ with a sliding-stage micrometer (Velmex Inc. Bloomfield NY, USA) interfaced with a computer. The software package COFECHA (Grissino-Mayer 2001) was used to quantitatively check for crossdating.

Every raw ring-width series was standardized using the ARSTAN program (Cook \& Holmes 1996). The series were fitted to a spline function with a $50 \%$ frequency response of 32 yrs, which was flexible enough to minimize the non-climatic variance and maximize the high-frequency climatic signal (Helama et al. 2004). The residuals obtained were pre-whitened by autoregressive modeling, giving dimensionless indexes that represent independent, normalized, and homogenized records of annual growth. The yearby-year arithmetic mean of the two series of standardized and pre-whitened tree-ring indexes from each tree, for the period held in common by both cores of the tree, was calculated to obtain an individual chronology Inter-annual variability of individual treering chronologies, prior to pre-whitening, was assessed using the standard statistic mean sensitivity $(M S)$ that describes the mean percentage change from each growth index to the next (Briffa \& Jones 1990).

\section{Climate data}

The climate data used in this study were monthly gridded time series for total precipitation (Prec), mean minimum (Tmin) and maximum (Tmax) temperature, and Palmer drought severity index (PDSI), obtained from the Climate Explorer of the Royal Netherlands Meteorological Institute (http:// climexp.knmi.nl/), for the $0.5^{\circ}$ longitude $\times$ $0.5^{\circ}$ latitude sector in which the study area is located. Series for Prec, Tmin and Tmax were obtained from the CRU TS 3 data set, period 1901-2006, while series for PDSI were obtained from the CRU self-calibrating PDSI data set, period 1901-2002. The PDSI combines air temperature, cumulative rainfall, and field water-holding capacity to give a standardized measure of soil water content (Dai et al. 2004). Monthly time series of water balance $(W B)$ were also calculated as (Thornthwaite 1948 - eqn. 2):

$$
W B=\text { Prec }- \text { PET }
$$

where Prec is the total precipitation and PET is the potential evapotranspiration, estimated as a function of monthly mean temperature and geographical latitude, according to the standard Thornthwaite's method (Thornthwaite 1948). Monthly data from May of the previous year (May(-1)) to October of the current growth year (Oct) were used, since this period includes both previous and current growing seasons in $Q$. robur (González-González et al. 2013). Monthly data was also averaged (Tmin, Tmax, PDSI) or summed (Prec, WB) in periods of three months to identify their main effects on individual radial growth at both monthly and seasonal scales.

\section{Climate sensitivity assessment}

The monthly or seasonal climatic variables that significantly influenced radial growth were identified by means of the percentage of trees that showed significant correlations with climate in 1971-2000, the most recent 30 -yrs period common to all individual treering chronologies prior to 2001, which was the wettest year on record for the site (Rozas \& García-González 2012). Individual climatic responses were calculated as bootstrapped correlations of the monthly and seasonal climatic time series with individual tree-ring chronologies. Bootstrapped correlations and their statistical significance were computed with the software DendroClim2002 (Biondi \& Waikul 2004). Most significant relations were revealed by the highest percentages of trees showing significant individual correlations with climate.

\section{Dependence of individual climatic} response on tree traits and competition

To explore the influence of tree age, size, and inter-tree competition on recent individual climatic response, the relationships between such factors and the previously calculated correlations of individual tree-ring chronologies with climatic variables were assessed. Since it has been previously established that tree bole diameter and crown dimensions, such as height and width, are strongly related in Quercus robur (Hemery et al. 2005, Cienciala et al. 2008), in this work I used DBH as a suitable indicator of total tree size.
According to the Kolmogorov-Smirnov test of normality, individual MS and correlation values with climate were not normally distributed. These data were normalized with the Fisher's transformation $z$ (Fisher 1921), also called the inverse hyperbolic tangent transformation, which allows the application of regression techniques on normally distributed correlations (Faller 1981 - eqn. 3):

$$
z=\frac{1}{2} \log _{e} \frac{1+r}{1-r}=\tanh ^{-1} r
$$

where $r$ represents the individual correlation of radial growth with climate or the chronology statistic MS. The proportion of significant individual correlations was calculated for every significant climatic variable affecting individual radial growth. The relationships of tree age, $\mathrm{DBH}$, and $C I$ with normalized MS were explored with correlation analysis.

Multiple linear regressions were used to study the relationships of tree age, DBH, and $C I$ with the normalized correlations of radial growth with climate. Based on the adjusted coefficients of determination from multiple regressions, a variation partitioning was additionally performed (Legendre 2008) that provided the relative importance of each significant predictor (tree age, DBH, $C I$ ) separately, and their joint effects, in modulating individual responses to climate. According to this procedure, the pure and joint effects of age, DBH and $C I$ were calculated, and transformed in a percentage of the total variation of the climatic response explained by every variable.

\section{Results}

Soils in the study stands were relatively homogeneous. Between $68.1-79.8 \%$ of soil material showed a size $<2 \mathrm{~mm}$, with a high content of organic matter ranging between 20.5-23.8\%, while soil $\mathrm{pH}$ was very similar in all the study stands, ranging between 3.63.9 (Tab. 1). Tree age at breast height ranged between 51 and 203 yrs, DBH between 13 and $57 \mathrm{~cm}$, and $C I$ between 0.15 and 8.58 . Mean $C I$ in the study stands varied between 1.4 and 2.5 (Tab. 1).

Age at breast height and size were positively related and shared $32.7 \%$ of their variance (Fig. 2a). Age and competition shared only $11.2 \%$ of their variance and showed an opposite relationship (Fig. 2b). However, size and competition shared $60.8 \%$ of their variance according to a power fit, with higher competition intensities for smaller trees (Fig. 2c).

The MS was independent of tree age and DBH $(p>0.05)$, but was significantly related to $C I$, which showed a negative correlation with $M S$ (Fig. 3). The proportion of trees with significant individual correlations with climate revealed a negative response of oak growth to previous June-August precipi- 

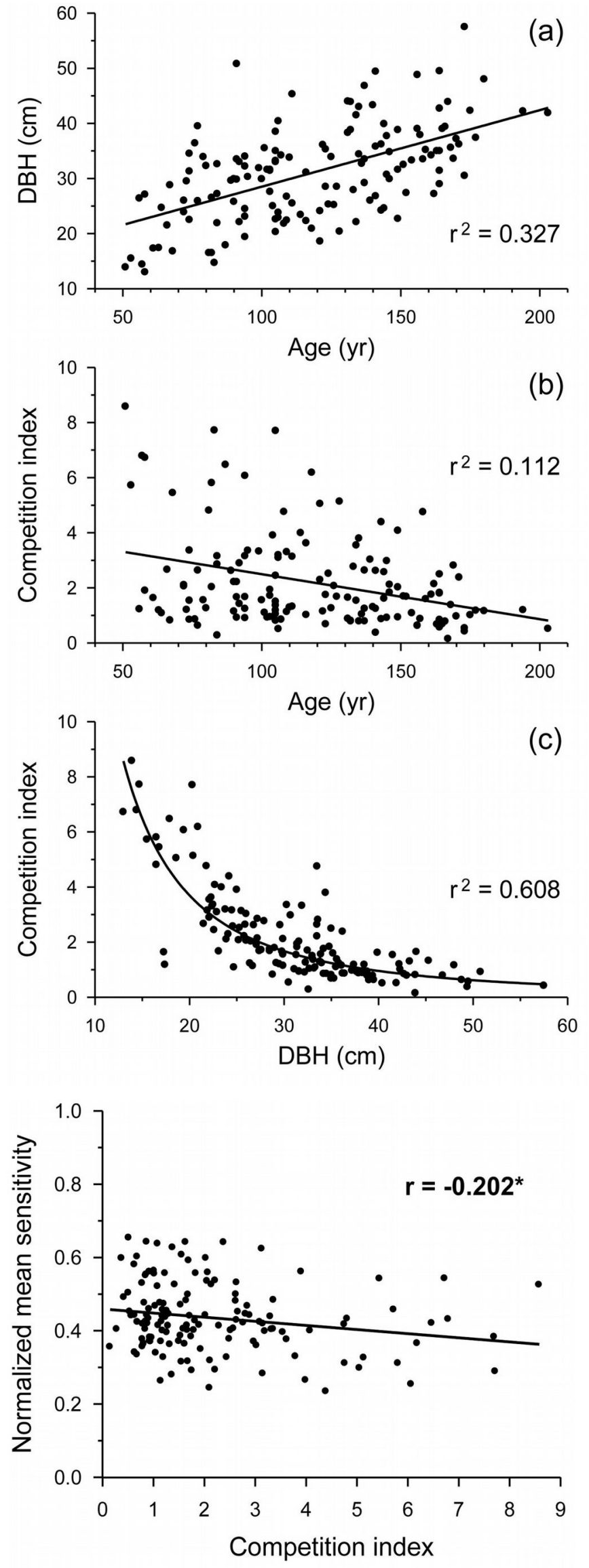

Fig. 2 - Relationships between (a) tree age at breast height and DBH, (b) tree age at breast height and competition index, and (c) DBH and competition in $Q$. robur trees from all study stands together. Linear or power fits and their coefficients of determination $\left(r^{2}\right)$, all of them highly significant $(p<0.001)$, are shown.
Fig. 3 - Relationships of the normalized mean sensitivity from individual radial growth chronologies, with the competition index in $Q$. robur trees from all study stands together. Linear fit, correlation coefficient $(r)$, and its statistical significance are shown. $(*): p<0.05$. 
Fig. 4 - Percentage of trees showing significant correlations with climate for monthly and seasonal precipitation (a), Palmer drought severity index (b), water balance (c), and minimum temperature (d), in the period 19712000. Positive and negative percentages refer to positive and negative correlations, respectively. Shaded areas correspond to correlations with seasonal climatic variables.

Fig. 5 - Relationships of the normalized bootstrapped correlations of radial growth with climate, with tree age, size (DBH), and competition in$\operatorname{dex}(C I)$ in $Q$. robur trees from all study stands together. Statistically significant $(p<0.05)$ and nonsignificant bootstrapped correlations are differentiated by solid and empty dots, respectively. Linear fits, correlation coefficients $(r)$, and their statistical significances are shown.

$(*): p<0.05$; $(* *): p<0.01$ $(* * *): p<0.001$
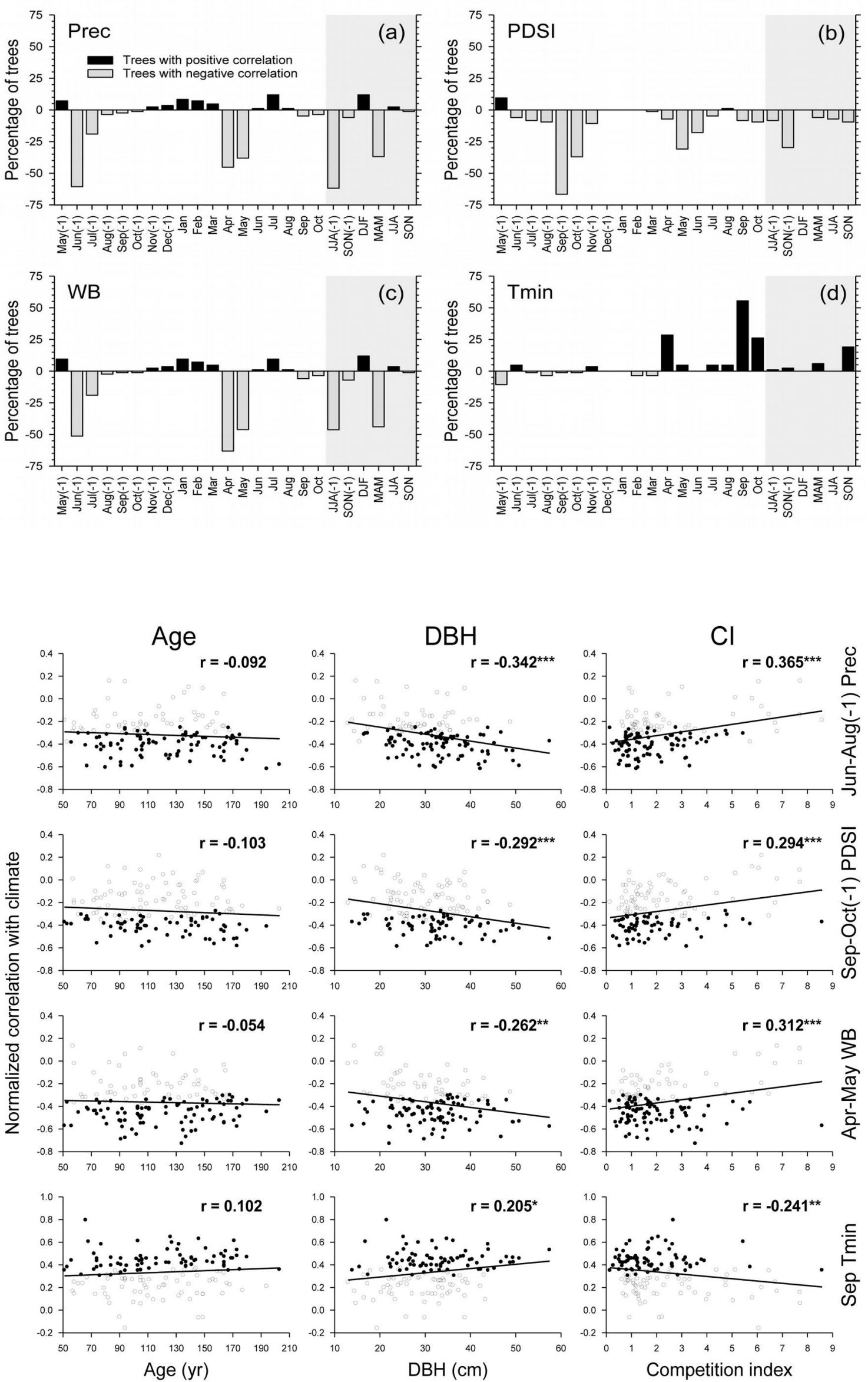
Tab. 2 - Adjusted coefficients of determination $\left(r_{\text {adj }}^{2}\right)$ and $p$ values of linear regression models for DBH, $C I$, and both $\mathrm{DBH}$ and $C I(\mathrm{DBH}+C I)$ modulating individual climatic responses (normalized bootstrapped correlations with climate time series) of tree-ring widths in 1971-2000. The fractions of variance of every climatic response explained by DBH alone, by the combination of DBH and $C I$, and by $C I$ alone, are shown. (Prec): precipitation; $(P D S I)$ : Palmer drought severity index; $(W B)$ : water balance; (Tmin): mean minimum temperature; (a): pure effect of DBH; (b): joint effect of DBH and $C I$; (c) pure effect of $C I$, calculated according to Legendre (2008).

\begin{tabular}{lccccccccc}
\hline \multirow{2}{*}{$\begin{array}{l}\text { Climatic } \\
\text { response }\end{array}$} & \multicolumn{2}{c}{ DBH } & \multicolumn{2}{c}{ CI } & \multicolumn{2}{c}{ DBH + CI } & \multicolumn{2}{c}{ Fraction of variance } \\
\cline { 2 - 9 } & $\boldsymbol{r}_{\text {adj }}^{2}$ & $\boldsymbol{p}$ & $\boldsymbol{r}^{2}$ adj & $\boldsymbol{p}$ & $\boldsymbol{r}_{\text {adj }}^{2}$ & $\boldsymbol{p}$ & $\mathbf{a}$ & $\mathbf{b}$ & $\mathbf{c}$ \\
\hline Jun-Aug(-1) Prec & 0.111 & $<0.001$ & 0.127 & $<0.001$ & 0.133 & $<0.001$ & 0.006 & 0.105 & 0.022 \\
Sep-Oct(-1) PDSI & 0.079 & $<0.001$ & 0.079 & $<0.001$ & 0.086 & 0.002 & 0.007 & 0.072 & 0.007 \\
Apr-May WB & 0.062 & 0.004 & 0.091 & $<0.001$ & 0.087 & 0.001 & -0.004 & 0.066 & 0.025 \\
Sep Tmin & 0.035 & 0.014 & 0.041 & 0.008 & 0.039 & 0.023 & -0.002 & 0.037 & 0.004 \\
\hline
\end{tabular}

tation (Fig. 4a), to previous September-October PDSI (Fig. 4b), and to April-May water balance (Fig. 4c). However, a high proportion of trees showed a positive relationship between minimum temperature in current September and oak growth (Fig. 4d).

Individual climatic response of oaks was independent of tree age $(p>0.05)$, while $\mathrm{DBH}$ and $C I$ showed significant linear relationships with individual response of oaks to all selected climatic factors (Fig. 5). Individual response to previous summer precipitation, previous autumn soil water content, and spring water balance were negatively correlated with $\mathrm{DBH}$ and positively correlated with $C I$. By contrast, individual response to September minimum temperature was positively correlated with DBH and negatively so with $C I$. More negative individual responses to water availability and positive to September minimum temperature were noticed for larger trees and trees under lower competition intensity.

Linear regressions showed that between $3.5-11.1 \%$ of the individual climatic response was related to DBH variation, between $4.1-12.7 \%$ was related to $C I$ variation, and between $3.9-13.3 \%$ was related to the combination of $\mathrm{DBH}$ and $C I$, all of them statistically significant (Tab. 2). The variation partitioning indicated that the greatest proportion of this variation $(3.7-10.5 \%)$ was related to the joint effect of DBH and $C I$, followed by the sole effect of $C I$ that was considerably lower $(0.4-2.5 \%)$. The individual effect of DBH was also reduced, and even negative, which indicates that $\mathrm{DBH}$ explains less variation than would be the case for random normal variables in the cases of Apr-May $W B$ and Sep Tmin (Legendre 2008).

\section{Discussion}

This study demonstrates that individual radial growth response to seasonal water excess and autumn temperature was independent of tree age in this multi-aged oak forest, but was modulated by the joint effect of tree size and inter-tree competition. This finding disagrees with previous studies on temperate deciduous oaks including $Q$. robur, $Q$. alba L., and $Q$. petraea (Matt.) Liebl., in which older trees showed a greater sensitivity to water availability than younger ones (Rozas 2005, Copenheaver et al. 2011), and different size classes showed a similar radial growth response to climate (Mérian \& Lebourgeois 2011, Zang et al. 2012). The straightforward relationship between tree size and age indicated that size increment was strongly associated with aging, a fact which complicates our understanding of whether changes in growth efficiency and vitality are a function of increasing age or size (Mencuccini et al. 2005). Intrinsic agedependent developmental shifts should be specifically related to cellular senescence, alterations of gene expression, or changing patterns of organ differentiation and function faced by trees as they become older (Day et al. 2002). However, it has been argued that age effects on the response to stresses may be more related to increasing size, or to the influence of size-mediated extrinsic factors, than on tree aging alone (Day et al. 2002, Phillips et al. 2003, Mencuccini et al. 2005). The findings of this study supported this interpretation, by showing that the joint effect of inter-tree competition and DBH significantly modulated the individual sensitivity to climate under relatively homogeneous soil conditions. The absence of age-related changes in the climatic signal may imply that, in this particular case, tree age would not affect the interpretation of potential dendroclimatic reconstructions based on oak tree-ring series.

Since DBH and crown size are strongly interrelated in Quercus robur (Hemery et al. 2005, Cienciala et al. 2008), and the associated error of DBH measurements is normally considerably lower in comparison to height measurements, the individual DBH has been used as a surrogate for total tree size. Intertree competition and tree DBH were strongly related in this case study, in all likelihood because dominant trees in less competitive environments had a greater capacity than suppressed trees to grow and become larger (Oliver \& Larson 1996). Tree size modulates the direction and intensity of the competitive interaction, since large trees generally had greater capacity to intercept solar radiation, acquire resources, and respond to stresses than small individuals (Thomas \& Winner 2002, Niinemets 2010). High competition levels reduced oak inter-annual growth variation $(M S)$, which is coherent with a less plastic growth and a weak climatic response of smaller trees in more competitive environments (Martín-Benito et al. 2008, Rozas \& Olano 2013). The finding that larger trees growing under lower competition levels were the most responsive to climate supports previous studies that compared climatic signal in tree-ring chronologies of sub-populations stratified by size or competition (Piutti \& Cescatti 1997, Mérian \& Lebourgeois 2011, Zang et al. 2012). The obtained findings were also supported by investigations on competition effects on tree response to climate at stand level (Hurteau et al. 2007, Gea-Izquierdo et al. 2009, Castagneri et al. 2012), which showed that competition can reduce, or mask, the climatic signal. In this case study, however, the effects of competition on dendroclimatic response occurs at individual level, but not at stand level. When radial growth of sampled individuals was averaged into a mean stand tree-ring chronology, there is no relationship between the climatic response of mean stand chronology and stand tree density or basal area (results not shown).

A previous study in this forest showed that oaks that died, as a consequence of the extremely rainy conditions in the year 2001, were smaller and had lived under higher competition levels than surviving oaks (Rozas \& García-González 2012). This evidence supports the theory that competition can predispose trees to the damaging effects of a climatic stress (Linares et al. 2010). Strongest competition usually occurs at the stem exclusion phase, where regular tree death is related to a set of individual traits such as small size, non-dominant position in the canopy, and decreasing growth trend (Oliver \& Larson 1996, Olano et al. 2009). It has been recently established that inter-tree competition is an important regulator of individual tree growth in diverse types of Iberian forests, causing much larger reductions in potential growth than would be caused by tree size or climate (Gómez-Aparicio et al. 2011). In addition, a recent dendroecological study on Juniperus thurifera L. in north-central Spain revealed that interference from neighboring trees can be more influential than local environmental heterogeneity in modulating the individual response to climate (Rozas \& Olano 2013). These previous findings, together with the evidences obtained from this study, indicate that inter-tree competition should be 
considered as a relevant size-mediated extrinsic factor that can potentially modulate individual radial growth variation and its response to climate.

The detrimental impact of water excess on radial growth found in this study disagrees with previous dendroclimatological studies on deciduous oaks. Drought in the active growing season is the climatic stress most frequently evidenced as limiting growth of pedunculate oak in northern, central, and southern Europe (Rozas 2005, Drobyshev et al. 2008, Friedrichs et al. 2009, Dolezal et al. 2010). In this case, however, the study area is on a windward slope that directly intercepts wet westerly fronts from the Atlantic Ocean on relatively homogeneous soils. Persistent soil water excess has been recorded since the 1960 s, with extremely rainy conditions in 2001, which induced a detrimental impact on oak growth (Rozas \& García-González 2012)

In addition, warm September conditions probably delayed the end of cambial activity and extended the active growing period, leading to the formation of wider rings. A recent study on cambial dynamics and phenology of $Q$. robur in northwest Spain showed that latewood formation usually ends in midSeptember, but further differentiation of latewood cells can continue for at least two more weeks when September temperature is elevated (González-González et al. 2013). Rising temperatures generally have a positive effect on growth of Iberian broadleaved tree species, particularly of deciduous Atlantic trees (Gómez-Aparicio et al. 2011). A positive effect of September temperature on the growth of trees under lower competition levels is consistent with the higher rates of cambial activity and the longer growing season found in dominant trees compared to suppressed ones (Rathgeber et al. 2011). The recent extension of the active growing season observed in many tree species throughout Europe, linked to global climate warming (Chmielewski \& Rötzer 2001, Lebourgeois et al. 2010), probably exacerbated the positive impact of September temperature on oak radial growth.

\section{Conclusions}

This study emphasizes the usefulness of an individual-based approach to study the potential modulation of growth responses to climate by intrinsic tree traits and extrinsic factors quantified at the individual level (Carrer \& Urbinati 2004, Rozas \& Olano 2013). Potential modulation of the climatic response is usually assessed by comparing climatic signals from mean chronologies of sub-populations stratified by age, size or competition. However, arbitrary classification of trees would artificially generate contrasting signals in mean sub-population chronologies, simply due to different sample replication (Esper et al. 2008). In addition, the traditional population-based approach magnifies the common signal in a population, and reduces the signal of climatic factors that affect only a fraction of trees (Carrer 2011, Rozas \& Olano 2013). Such concerns may be avoided by using an individual-based approach, which informs about the relative contribution of factors modulating the climatic response, as this study revealed. Further research is required in order to better understand the prevalence and extent of individual dendroclimatic responses potentially modulated by intrinsic tree traits and extrinsic factors in different tree species.

\section{Acknowledgements}

The author thanks Enrique Diz, Adrián González, Sonia Lamas, Aurea Pazos and María José Rozados for field and laboratory assistance, José Miguel Olano and three anonymous reviewers for useful suggestions on an earlier draft of this paper, and David Brown for English language assistance. The author benefited from research contracts by INIA-Xunta de Galicia and CSIC, partially funded by the European Social Fund. This study was supported by Consellería de Innovación e Industria, Xunta de Galicia (PGIDIT06PXIB502262PR), and Instituto Nacional de Investigación Agraria y Alimentaria, Ministerio de Ciencia e Innovación (RTA 2006-00117)

\section{References}

Biondi F, Waikul K (2004). DENDROCLIM2002: A C++ program for statistical calibration of climate signals in tree-ring chronologies. Computers \& Geosciences 30: 303-311. - doi: 10.1016/ j.cageo.2003.11.004

Briffa K, Jones PD (1990). Basic chronology statistics and assessment. In: "Methods of Dendrochronology: Applications in the Environmental Sciences" (Cook ER, Kairiukstis LA eds). Kluwer, Dordrecht, The Netherlands, pp. 137-152.

Calvo de Anta R, Macías Vázquez F (2002). Mapa de solos de Galicia, Escala 1:50.000 [Soil Map of Galicia, Scale 1:50.000]. Consellería de Medio Ambiente, Xunta de Galicia, Santiago de Compostela, Spain. Ponte Caldelas 186: 5-10. [in Spanish]

Carrer M (2011). Individualistic and time-varying tree-ring growth to climate sensitivity. PLoS ONE 6 (7): e22813. - doi: 10.1371/journal.pone. 0022813

Carrer M, Urbinati C (2004). Age-dependent treering growth responses to climate in Larix decidua and Pinus cembra. Ecology 85: 730-740. doi: 10.1890/02-0478

Castagneri D, Nola P, Cherubini P, Motta R (2012). Temporal variability of size-growth relationships in a Norway spruce forest: the influences of stand structure, logging, and climate. Canadian Journal of Forest Research 42: 1-11. doi: 10.1139/x2012-007

Chmielewski F-M, Rötzer T (2001). Response of tree phenology to climate change across Europe. Agricultural and Forest Meteorology 108: 101112. - doi: 10.1016/S0168-1923(01)00233-7 Cienciala E, Apltauer J, Exnerová Z, Tatarinov F (2008). Biomass functions applicable to oak trees grown in Central-European forestry. Journal of Forest Science 54:109-120 [online] URL: http://81.0.228.28/publicFiles/01003.pdf

Cook ER, Holmes RL (1996). Guide for computer program ARSTAN. In: “The International TreeRing Data Bank Program Library Version 2.0 User's Manual" (Grissino-Mayer HD, Holmes RL, Fritts HC eds). Laboratory of Tree-Ring Research, University of Arizona, Tucson, AZ, USA, pp. 75-87.

Copenheaver CA, Crawford CJ, Fearer TM (2011). Age-specific responses to climate identified in the growth of Quercus alba. Trees 25: 647-653. - doi: 10.1007/s00468-011-0541-2 Dai A, Trenberth KE, Qian T (2004). A global data set of Palmer Drought Severity Index for 1870-2002: relationship with soil moisture and effects of surface warming. Journal of Hydrometeorology 5: 1117-1130. - doi: 10.1175/JHM386.1

Day ME, Greenwood MS, Díaz-Sala C (2002). Age- and size-related trends in woody plant shoot development: regulatory pathways and evidence for genetic control. Tree Physiology 22: 507-513. - doi: 10.1093/treephys/22.8.507

De Luis M, Novak K, Cufar K, Raventós J (2009). Size mediated climate-growth relationships in Pinus halepensis and Pinus pinea. Trees 23: 1065-1073. - doi: 10.1007/s00468-009-0349-5

Dolezal J, Mazurek P, Klimesová J (2010). Oak decline in southern Moravia: the association between climate change and early and late wood formation in oaks. Preslia 82: 289-306.

Drobyshev I, Niklasson M, Eggertsson O, Linderson H, Sonesson K (2008). Influence of annual weather on growth of pedunculate oak in southern Sweden. Annals of Forest Science 65 (5): 512. - doi: 10.1051/forest:2008033

Esper J, Niederer R, Bebi P, Frank D (2008). Climate signal age effects - evidence from young and old trees in the Swiss Engadin. Forest Ecology and Management 255: 3783-3789. - doi: 10.1016/j.foreco.2008.03.015

Faller AJ (1981). An average correlation coefficient. Journal of Applied Meteorology 20: 203 205. - doi: 10.1175/1520-0450(1981)020<0203: AACC $>2.0 . \mathrm{CO} ; 2$

Fisher RA (1921). On the "probable error" of a coefficient of correlation deduced from a small sample. Metron 1: 3-32. [online] URL: http:// digital.library.adelaide.edu.au/dspace/bitstream/2 440/15169/1/14.pdf

Friedrichs DA, Büntgen U, Frank DC, Esper J, Neuwirth B, Löffler J (2009). Complex climate controls on $20^{\text {th }}$ century oak growth in CentralWest Germany. Tree Physiology 29: 39-51. - doi: 10.1093/treephys/tpn003

Gea-Izquierdo G, Martín-Benito D, Cherubini P, Cañellas I (2009). Climate-growth variability in Quercus ilex L. west Iberian open woodlands of different stand density. Annals of Forest Science 
66: 802p1-802p12. - doi: 10.1051/forest/2009 080

Gómez-Aparicio L, García-Valdés R, Ruíz-Benito P, Zavala MA (2011). Disentangling the relative importance of climate, size and competition on tree growth in Iberian forests: implications for forest management under global change. Global Change Biology 17: 2400-2414. - doi: 10.1111/j. 1365-2486.2011.02421.x

González-González BD, García-González I, Vázquez-Ruiz RA (2013). Comparative cambial dynamics and phenology of Quercus robur L. and Q. pyrenaica Willd. in an Atlantic forest of the northwestern Iberian Peninsula. Trees 27: 1571 1585. - doi: 10.1007/s00468-013-0905-x

Grissino-Mayer HD (2001). Evaluating crossdating accuracy: a manual and tutorial for the computer program COFECHA. Tree-Ring Research 57: 205-221. [online] URL: http://www.treeringsociety.org/TRBTRR/TRRvol57_1_115-124.pdf Helama S, Lindholm M, Timonen M, Eronen M (2004). Detection of climate signal in dendrochronological data analysis: a comparison of tree-ring standardization methods. Theoretical and Applied Climatology 79: 239-254. - doi: 10.1007/s00704-004-0077-0

Hemery GE, Savill PS, Pryor SN (2005). Applications of the crown diameter-stem diameter relationship for different species of broadleaved trees. Forest Ecology and Management 215: 285 294. - doi: 10.1016/j.foreco.2005.05.016

Hurteau M, Zald H, North M (2007). Species-specific response to climate reconstruction in upperelevation mixed-conifer forests of the western Sierra Nevada, California. Canadian Journal of Forest Research 37: 1681-1691. - doi: 10.1139/ X07-028

Lebourgeois F, Pierrat J-C, Perez V, Piedallu C, Cecchini S, Ulrich E (2010). Simulating phenological shifts in French temperate forests under two climatic change scenarios and four driving global circulation models. International Journal of Biometeorology 54: 563-581. - doi: 10.1007/ s00484-010-0305-5

Legendre P (2008). Studying beta diversity: ecological variation partitioning by multiple regression and canonical analysis. Journal of Plant Ecology 1: 3-8. - doi: 10.1093/jpe/rtm001

Linares JC, Camarero JJ, Carreira JA (2010) Competition modulates the adaptation capacity of forests to climatic stress: insights from recent growth decline and death in relict stands of the Mediterranean fir Abies pinsapo. Journal of Ecology 98: 592-603. - doi: 10.1111/j.1365-2745. 2010.01645.x

Lorimer CG (1983). Tests of age-independent competition indices for individual trees in natural hardwood stands. Forest Ecology and Mana- gement 6: 343-360. - doi: 10.1016/0378-1127 (83)90042-7

Martín-Benito D, Cherubini P, del Río M, Cañellas I (2008). Growth response to climate and drought in Pinus nigra Arn. trees of different crown classes. Trees 22: 363-373. - doi: 10.10 07/s00468-007-0191-6

Martín-Benito D, Kint V, del Río M, Muys B, Cañellas I (2011). Growth responses of westMediterranean Pinus nigra to climate change are modulated by competition and productivity: past trends and future perspectives. Forest Ecology and Management 262: 1030-1040. - doi: 10.101 6/j.foreco.2011.05.038

Mencuccini M, Martínez-Vilalta J, Vanderklein D, Hamid HA, Korakaki E, Lee S, Michiels B (2005). Size-mediated ageing reduces vigour in trees. Ecology Letters 8: 1183-1190. - doi: 10.11 11/j.1461-0248.2005.00819.x

Mérian P, Lebourgeois F (2011). Size-mediated climate-growth relationships in temperate forests: a multi-species analysis. Forest Ecology and Management 261: 1382-1391. - doi: 10.101 6/j.foreco.2011.01.019

Niinemets U (2010). Responses of forest trees to single and multiple environmental stresses from seedlings to mature plants: past stress history, stress interactions, tolerance and acclimation. Forest Ecology and Management 260: 16231639. - doi: 10.1016/j.foreco.2010.07.054

Olano JM, Laskurain NA, Escudero A, de la Cruz M (2009). Why and where do adult trees die in a young secondary temperate forest? The role of neighbourhood. Annals of Forest Science 66 (1): 105. - doi: 10.1051/forest:2008074

Oliver CD, Larson BC (1996). Forest stand dynamics (update edn). Wiley, New York, USA, pp. 467.

Phillips N, Bond BJ, McDowell NG, Ryan MG, Schauer A (2003). Leaf area compounds heightrelated hydraulic costs of water transport in Oregon white oak trees. Functional Ecology 17: 832840. - doi: 10.1111/j.1365-2435.2003.00791.x

Piutti E, Cescatti A (1997). A quantitative analysis of the interactions between climatic response and intraspecific competition in European beech. Canadian Journal of Forest Research 27: 277 284. - doi: 10.1139/x96-176

Rathgeber CBK, Rossi S, Bontemps J-D (2011). Cambial activity related to tree size in a mature silver-fir plantation. Annals of Botany 108: 429438. - doi: 10.1093/aob/mcr168

Rossi S, Deslauriers A, Anfodillo T, Carrer M (2008). Age-dependent xylogenesis in timberline conifers. New Phytologist 177 (1): 199-208. doi: 10.1111/j.1469-8137.2007.02235.x

Rozas V (2003). Tree age estimates in Fagus sylvatica and Quercus robur: testing previous and improved methods. Plant Ecology 167: 193-212. - doi: 10.1023/A:1023969822044

Rozas V (2005). Dendrochronology of pedunculate oak (Quercus robur L.) in an old-growth pollarded woodland in northern Spain: tree-ring growth responses to climate. Annals of Forest Science 62: 209-218. - doi: 10.1051/forest:2005 012

Rozas V, DeSoto L, Olano JM (2009). Sex-specific, age-dependent sensitivity of tree-ring growth to climate in the dioecious tree Juniperus thurifera. New Phytologist 182: 687-697. - doi: 10.1111/j.1469-8137.2009.02770.x

Rozas V, García-González I (2012). Too wet for oaks? Inter-tree competition and recent persistent wetness predispose oaks to rainfall-induced dieback in Atlantic rainy forest. Global and Planetary Change 94-95: 62-71. - doi: 10.1016/j.gloplacha.2012.07.004

Rozas V, Olano JM (2013). Environmental heterogeneity and neighbourhood interference modulate the individual response of Juniperus thurifera tree-ring growth to climate. Dendrochronologia 31: 105-113. - doi: 10.1016/j.dendro.201 2.09.001

Szeicz JM, MacDonald GM (1994). Age-dependent tree-ring growth responses of subarctic white spruce to climate. Canadian Journal of Forest Research 24: 120-132. - doi: 10.1139/x94-017

Thomas SC (2010). Photosynthetic capacity peaks at intermediate size in temperate deciduous trees. Tree Physiology 30: 555-573. - doi: 10.1093/tree phys/tpq005

Thomas SC, Winner WE (2002). Photosynthetic differences between saplings and adult trees: an integration of field results by meta-analysis. Tree Physiology 22: 117-127. - doi: 10.1093/treephys/ 22.2-3.117

Thornthwaite DW (1948). An approach toward a rational classification of climate. Geographical Review 38: 55-94. - doi: 10.2307/210739

Vieira J, Campelo F, Nabais C (2009). Age-dependent responses of tree-ring growth and intraannual density fluctuations of Pinus pinaster to Mediterranean climate. Trees 23: 257-265. - doi 10.1007/s00468-008-0273-0

Yamaguchi DK (1991). A simple method for cross-dating increment cores from living trees. Canadian Journal of Forest Research 21: 414416. - doi: 10.1139/x91-053

Yu G, Liu Y, Wang X, Ma K (2008). Age-dependent tree-ring growth responses to climate in Qilian juniper (Sabina przewalskii Kom.). Trees 22: 197-204. - doi: 10.1007/s00468-007-0170-y Zang C, Pretzsch H, Rothe A (2012). Size-dependent responses to summer drought in Scots pine, Norway spruce and common oak. Trees 26: $557-$ 569. - doi: 10.1007/s00468-011-0617-z 